\title{
Teologisk erindringsforskning
}

Nærværende nummer af Dansk Teologisk Tidsskrift er et temanummer om erindring. Der tages afsæt i den erindringsforskning, som flere ansatte ved Afdeling for Bibelsk Eksegese i København har arbejdet med de sidste år. Artiklerne afspejler den spredning, som denne retning lægger op til, både hvad angår de involverede fagdiscipliner og valget af undersøgelsesmateriale.

Den sociale erindringsforskning har efter mange forskeres opfattelse sine rødder i den franske sociolog Maurice Halbwachs' arbejder. Med sin 'kollektive erindring' satte Halbwachs det sociale på dagsordenen som forudsætningen for erindring, Sociale grupper, f.eks. familier, religiøse grupper, samfundsklasser, udgør erindringens rammer. Halbwachs mente ikke, at fortiden kan opbevares objektivt i den enkeltes bevidsthed. I stedet genkalder vi den gennem brugen af ord i den kommunikative vekselvirkning med gruppen.

Hvor Halbwachs lagde hovedvægten på sproget, vælger den britiske sociolog, Paul Connerton, at undersøge kroppen som medium for kollektiv erindring. Connerton fokuserer på kropslig praksis, herunder "kommemorative ceremonier". Sådanne ceremonier udfolder sig ifølge Connerton som koreograferede bevægelser og formaliserede verbale ytringer, der har til formål at skabe en højtidelig stemning. Sådanne ceremonier refererer gerne til nøglebegivenheder i et fællesskabs dominerende fortællinger og gentages som regel med mellemrum, hvorved fortællingerne indarbejdes i kroppen. Connerton viser også, hvordan andre former for kropslig praksis kan mediere fortiden, og han demonstrerer, hvordan kropslige praksisser implicit viderefører kulturspecifikke kategorier, normer og værdier. Den kropsligt medierede erindring arbejder således på et praktisk plan, hvorved normer, værdier og dominerende fortællinger indlejres i kroppen i et givet erindringsfællesskab.

Den tyske ægyptolog Jan Assmann beskriver i Das Kulturelle Gedächtnis to forskellige aspekter af den kollektive erindring. "Kommunikativ erindring" medieres i daglig kommunikation mellem mennesker og er baseret på gruppemedlemmers erfaringer. Den overlever typisk en periode på ca. 80-100 år, hvorefter den går over i glemslen. Herefter nås nemlig et tidløst vakuum, som skiller den kommunikative erindring fra det, der ikke længere kan erindres gennem dagligdags kommunikative midler, og som da må videreføres gennem traditionen. Dette kalder Assmann "kulturel erindring". Hvad kommunikation er for den kommunikative erindring, er traditionen altså for den kulturelle. Kulturel erindring vedrører en absolut fortid, hinsides dagligdags erfaring og derfor også hinsides det tidløse vakuum. Den må konstrueres, er gerne institutionaliseret og opretholdt af specialister. 
Assmann anerkender, at ceremonier og ritualer spiller en afgørende rolle i skriftløse folks kulturelle erindring, men understreger, at den hos skriftkulturer primært er forbundet med tekster.

Sluttelig skal her nævnes den franske historiker Pierre Nora og en række ligesindede kolleger, der har dannet skole ved at fokusere på undersøgelser af steder med særlig stærke koncentrationer af kollektivt fransk arvegods. Sådanne steder blev af Nora betegnet som "erindringssteder". Ved erindringssted forstod Nora en hvilken som helst enhed, materiel eller ikke-materiel, som pga. menneskers vilje eller tidens virkning har fået en symbolsk status i en given social gruppes erindring og arv.

Pernille Carstens viser i sit bidrag, hvordan erindringsforskningen, udover tekstlige studier, også har åbnet en mulighed for at undersøge arkæologisk materiale og i bredere forstand landskabets og stedets betydning for det enkelte menneske og for et folk, og det gør hun med Mirjam som eksempel. I den kulturelle erindring ser man, hvordan fortiden er medieret, hvordan erindringen er produceret og cirkuleret, og kan afdækkes som et indeks.

Niels Peter Lemche ridser forholdet mellem erindringen og historien op og viser hvordan Det Gamle Testamente ikke er historisk i moderne forstand, idet fortiden bliver anvendt og forstået didaktisk. Der er tale om en erindring om fortiden konstrueret af en elitær gruppe, der kunne læse og skrive. Denne gruppe har skrevet en national historie, som har sine propagandistiske årsager $\mathrm{i}$ at betone Jerusalems forrang. Trine B. Hasselbalch er i sit bidrag interesseret i at kortlægge en strategi, som den historisk orienterede forskning i bibelfagene ikke har taget højde for, nemlig selve det processuelle i at skabe en fortælling. Hun fokuserer på det spatiale aspekt $\mathrm{i}$ analysen af teksterne, og lader Davidsfortællingen være et eksempel herpå. Samtidig peger hun også på palimpsesten i erindringen om landskabet i Samuelsbøgerne.

Erindringsstedet belyses i Bo Dahl Hermansens artikel om en landsby i Palæstina, hvorfra befolkningen i 1948 blev forvist. Forestillinger om "ejerskab" til et sted er en udfordring. Det gælder også at skulle leve med et savn og holde erindringen ved lige ved fortællinger om et sted, som får status af diaspora og dermed afdækker en forestilling vi kender tilbage i antikken. Erindringen kan både være individuel eller bundet til gruppen og er med til at skabe identitet. Det visser Michael Perlt i sin artikel om gruppeidentitet i krisetider, knyttet til et bestemt område eller nation. Det sker ved at analysere en prædiken af Ludvig Helveg Palmesøndag 1864 under krigen i Schleswig-Holstein. Perlt viser betoningen af den sociale performance i forsøget på at styrke den kollektive bevidsthed i forsøget på at tolke fortiden, forstå nutiden og nære håb for fremtiden. 